\title{
THE ROLES OF MOSQUE LIBRARIES THROUGH HISTORY
}

\section{Nurdin Laugu}

Faculty of Adab, Sunan Kalijaga State Islamic University Yogyakarta

\begin{abstract}
Since the formation of the Islamic society by prophet Mubammad, mosque libraries fulfilled several important roles that deserve scholarly attention. Therefore, this article elicits the significance of these various roles within Muslim societies through Islamic history. Until present day, almost all mosque libraries provide a variety of collections, concerning both religious and non-religious issues, such as social science and education. In line with these roles, this paper presents different examples of mosque libraries that, through history, contributed significantly to the development of Islamic civilization, like the library of the al-Azhar mosque in Egypt, the Grand Mosque Library in Cordova, etc. In addition, several aspects determining the (in)significance of mosque libraries through history, such as library management and factors contributing to the stagnation of mosque libraries, are investigated.
\end{abstract}

Keywords: Mosque Libraries, Islamic Libraries, Muslim Libraries, Mosque, Islamic History

\section{A. Introduction}

Historically, mosque libraries have played important roles in the development of Islamic and human civilization, particularly in promoting education for the Islamic society. Thus, in order to comprehend the Islamic religion, the mosque libraries are among the most significant phenomena in need of investigation, in order to present 
Islamic religiosity and culture in a comprehensive perspective. ${ }^{1}$ Islam, in an Arabic etymology, refers to obedience and loyalty to all instructions of God, which were delivered through His prophets and messengers continuously. In Islam, it is believed that Muhammad is the final prophet as well as the messenger who was sent to the people to achieve peace on the earth. This statement, explicitly written in the holy Qur'an, consists of basic principles about transcendental guidance for human beings, whether they are still living or already passed into the hereafter. ${ }^{2}$

The seventh century, known as the century of the emergence of Islam, is considered a new era in the long history of the Near East. The coming of the new religion has influenced almost all aspects of human life in history. Even though the influences seem to be marginalized in a global context, the teaching of the religion made a significant contribution to the development of knowledge and scientific institutions, such as Bait al-Hikmah, in the time of the caliphs alMakmun and al-Azhar during the reign of Solahuddin al-Ayyubi. ${ }^{3}$ This development is a logical process encountering a basic Islamic concept which the holy Qur'an illustrates as follows:

“1) Proclaim! (or read) in the name of thy Lord and Cherisher, Who created-2) Created man, out of a (mere) clot of congealed blood: 3) Proclaim! And thy Lord is Most Bountiful,- 4) He Who taught (the use of) the Pen,- 5) Taught man that which he knew not." ${ }^{\prime 4}$

1 Eche, Youssef, Les Bibliothèques Arabes: Publiques et Semi-Publiques en Mèsopotamie, en Syrie et Égypte au Moyen Age, Damas, 1967, p. 1-6. See also Gurgis Awad in his book entitled Khizanah al-Kutub al-Qadimah fil-Iraq, which is a translation from the title Ancient Libraries of Iraq: From the Earliest Times to the Year 1000 A.H. (1591 A.D.) published by al-Maarif Printing Press of Baghdad in 1948.

2 The most popular vision of Islam stands for peace for all creatures, not only for human beings. This is illustrated in many verses in the Holy Qur'an. One of them is cited to give a picture of the above vision, namely chapter 21: 107: "We sent thee not, but as a mercy for all creatures."

3 Mackensen, Ruth Stellhorn, "Background of the History of Muslim Libraries" in The American Journal of Semitic Languages and Literatures, Vol. 51 (October, 1934-July, 1935: 123).

${ }^{4}$ Ali, Abdullah Yusuf, The Holy Qur'an: Text and Translation, Kuala Lumpur: Islamic Book Trust, 1994, p. 626 and see also the verses of the Qur'an (96:1-5). 
In relation to the historical context of an illiterate society, in which extensive oral tradition and lack of critical thinking fulfil significant roles, the coming of the Qur'an has led to revolutionary ideas towards all aspects of human life. Regardless of the spiritual contents of the Qur'an, it also provides information and emphasizes that learning is the compulsory activity for each Muslim. Therefore, it is a significant argument contesting that the Qur'anic messages offer a comprehensive conceptual foundation of the verses of the Qur'an, covering both transcendental and physical phenomena.

Among Muslim society, it is strongly believed that the founding father of Islamic education is the prophet Muhammad himself, albeit he is famously known to be an illiterate person (al-ummiyy) unable both to read and write. He has been largely acknowledged as a distinguishing promoter of knowledge both religious and mundane, by which he proved that he never gave up to teach his followers during his life. His teachings consisted of both transcendental and physical insights, which later became general and fundamental guidelines for human life in order to achieve peace. In terms of both kinds of knowledge, he is clearly accounted to have instructed his friends and followers to become the lovers of knowledge, because doing so is compulsory for all Muslim, men and women. ${ }^{5}$ In such circumstances, the first thing offered by the Muslim prophet is the source of knowledge, which is regarded as a divine knowledge, the holy Qur'an. This kind of learning had been delivered through different occasions such as sermons and lectures. It is obviously issued that the Qur'an describes the prophet as a qualified teacher for divine messages. He was the person developing a career based on the name of God, and everything he had done was based on expectations towards Allah. All the messages, both in the form of sermons and teachings, were exposed in different mosques which, in that time, were considered important in having institutional activities. ${ }^{6}$

${ }^{5}$ Ibn Majah, Sunan Ibn Majah (Chapter Fadhl al-'Ulama wa al-Khas ala Talab al'Ilmi, $1^{\text {st }}$ Section/Electronic Version), p. 260.

6 Laugu, Nurdin, "Mosque Libraries in the Netherlands: An Explorative Study" in Mukaddimab: Jurnal Studi Islam, No. 19 TH. XI (2005); Mirza Tahir Ahmad, Revelation, Rationality, Knowledge, and Truth, United Kingdom: Islam International Publications, 1998, p. 3-10. 
Based on these phenomena, the writer is going to find out to what extent mosques have become centres for community activities covering almost all aspects of human life, particularly the education and learning. Furthermore, this study is going to investigate the issues of mosque collections, that later grew to become the mosque libraries ${ }^{7}$ as we know them nowadays, functioning to support the mosques in achieving their goals in terms of religious and social missions. Finally, systems and operational standards, such as fundamental components of the mosque libraries, will be analysed in connection with external and internal factors such as barriers in developing collections in the mosques.

\section{B. The Mosque and its Library as a Centre for Muslim Activities}

As mentioned above, mosque libraries have been involved in and have contributed to the development of Islamic civilization and scientific pioneering all over the world. Here we are, therefore, going to discover what role is significantly played by the mosque libraries in order to support their umbrella institutions, the "mosques." In regard to these ideas, the below I have listed several important functions or roles ascribed to the mosque which are considered crucial to create a dynamic society, both religious and mundane, and both spiritual and physical. ${ }^{8}$

${ }^{7}$ For further information about the empirical reality of mosque libraries in Indonesia, it is significant to see an article written by Nuning Hasanah, a graduate of Library and Information Studies, Faculty of Adab UIN Sunan Kalijaga Yogyakarta, entitled "Peranan Perpustakaan Masjid dalam Menunjang Pendidikan Sepanjang Hayat: Pengalaman Perpustakaan Masjid Syuhada Yogyakarta", in Fibris: Jurnal Ilmu Perpustakaan dan Informasi (Volume 1, Edition 1, 2006) and a book concerning mosque libraries written by Lasa HS, a lecturer of the Department of Library and Information Studies UIN Sunan Kalijaga Yogyakarta.

${ }^{8}$ Such an environment can be clearly seen in the cases of Muslim minorities, such as the Muslim community in the Netherlands and communities in other European countries, where the Muslims feel that they have to maintain their own Islamic identity which is different from the majority. Therefore, they use mosques as the strategic place to do so. See also Lokman I. Meho and Mona A. Nsouli in their compilation entitled Libraries and Information in the Arab World, London: Green Wood Press, 1999, p. 1-2. 


\section{The Mosque as a Place of Worship}

The word "mosque" in Arabic language is masjid, meaning a place of praying or a place of doing ritual activities for God. This meaning is shown by the holy Qur'an as follows.

"Do ye make the giving of drink to pilgrims, or the maintenance of the Sacred Mosque, equal to (the pious service of those who believe in God and the Last Day, and strive with might and main in the cause of God? They are not comparable in the sight of God..."

"And who is more unjust than he who forbids that in places for worship of God, God's name should be celebrated?-whose zeal is (in fact) to ruin them..."10

Concerning the utilization of mosques (masjid), al-Ujhuri investigates that the word "masjid" is derived from word sajada, meaning "to knee down," which is a fundamental move in praying. Furthermore, al-Zarkashi writes that the word "masjid" is used to name the place of Muslim worship, because sujud or 'to knee down' is one of the most ritual actions of prayers for Muslims in encountering their God. In the Qur'an, there are several verses illustrating this kind of phenomena, the following being one of them:

"Among His signs are the Night and the Day, and the Sun and the Moon. Adore not the sun and the moon, but adore God, Who created them, if it is Him ye wish to serve."11

In a long article written in The Encyclopaedia of Islam, Pedersen argues that the genesis of the word "masjid" is assumed to have originated from several ancient languages such as Aramaic, Nabataean or Syrian and Amharic Ethiopian languages. ${ }^{12}$ According to the Dictionary of Islam, the word "masjid" refers to a place of prostration by which people of prayers prove their obedience to their greatest creator. McClenahan notes that "masjid" has been used as a place of adoration. Another opinion supporting this meaning is explored by Goitein, i.e.

9 Ali, The Holy, p. 171 and see also the verses of the Qur'an (9: 19).

${ }^{10} \mathrm{Ibid}$., p. 16 and see also the verses of the Qur'an (2: 114).

${ }^{11}$ Ibid., p. 475 and see also the verses of the Qur'an (41:37).

${ }^{12}$ See "Masdjid" in the Encyclopaedia of Islam (WebCD Edition by Brill Academic Publishers, 2003). 
the word "masjid", derived from Arabic, literally means 'a place for kneeing down'. ${ }^{13}$ Consequently, in order to appreciate the importance of mosques among Muslim society, we have to understand the importance of praying in Islam, because it has become a fundamental basis for the emergence of mosques in the society. It is also one of the five basic pillars of belief in the concept of Islam. ${ }^{14}$

Furthermore, the word jami is another word having a similar meaning as the word "masjid", but it is derived from the word jama', meaning 'to come together'. This word is also supposed to be associated with the word juma', meaning 'the day of Jumat (Friday)'. In his book concerning mosques, Mahir explains that the word jami' means 'masjid where the Jumat-prayer is conducted'. He furthers his explanation on the differences between the two words; he observes that in the beginnings of Muslim era, the places of worship for Muslims were called masjid. But when Islam came to different places and many people came to embrace it, many different mosques were built. In such situation, the mosques associated with the main mosques were called masjid jami", where Muslims come together to perform jumat praying. Several years later, it had a new place in the context of cultural, social, and political dimensions. Then, masjid jami ${ }^{\varepsilon}$ became the places where people came together for worship and the Khalifs or governors came to talk to their people. ${ }^{15}$

In his voluminous book concerning mosques (masjid) and schools (madrasah) in Kairo, Fikri elicits the historical aspects of the emergence and the characteristics of the mosque "jami'." He argues that one of the first works done by Muslims after winning wars was building mosque "jami" in order for the people to come together to perform Friday (Jumat) praying. They were very careful in terms of choosing the land for the mosque so that it was never far from the residence of the governor, which is known as Dār al-Imärah. As an historian, al-Makrizi notes that building mosque "jami" is a tradition originated from the

\footnotetext{
${ }^{13}$ Sibai, Mohamed Makki. Mosque Libraries: An Historical Study, London: Mansell Publishing Limited, 1987, p. 7.

${ }^{14}$ Al-Bukhari, Shabih al-Bukhari (Chapter Su'al al-Jibril al-Nabiy SAW, ${ }^{\text {st }}$ Section/ Electronic Version), p. 86.

${ }^{15}$ Sibai, Mosque, p. 8.
} 
rule of Umar Ibn al-Khattab, the second caliph in Islam, under whom the mosques have firstly been used for praying Jumat. Beside the mosque jami $i^{\kappa}$ each group or tribe was instructed to provide a mosque for its own group or tribe. ${ }^{16}$

Based on the above facts, it is clear that the mosque was meant to be a place for performing religious-ritual activities. On such activities, the Muslims should perform them in a right way following certain rules with reference to the rituals in Islamic concepts. In order to get a good understanding of the practise of these Islamic rituals, the institutional process was held very important, probably through teachers or even by learning independently out of collections of the Qur'an and the Hadis, etc. As a result, the mosque libraries emerged to provide such collections in order to support the learning process among Muslims communities. Such conditions provoked the acquisition of different sources, covering religious and social volumes which were placed in the mosques and have since then been regarded as mosque libraries. ${ }^{17}$

\section{The mosque as a Centre for Community}

As a centre for community, a mosque plays at least three basic roles, those are social, political, and educational. ${ }^{18}$ Each role has a different significance depending on the different context of places and time. In many cases, however, mosques are commonly designed to provide anything needed by people living around them. In such circumstances, the emergence of mosque libraries becomes important to help achieve the objectives of mosques in the Islamic society within social, political, and educational contexts. ${ }^{19}$

In relation to the role of mosques as a centre for community, I would like to illustrate my short experience concerning the topic when I did my field research on the mosque libraries in the Netherlands.

${ }^{16}$ Ibid., p. 6-8.

${ }^{17}$ Spies-Aligarh, Von Otto, "Die Bibliotheken des Hidschas" in Zeitschrift der Deutschen Morgenländischen Gesellschaft, Band 90 (Neue Folge Band 15), Leipzig (1936: 86-89).

${ }^{18}$ Shadiq, W.A.R. and P.S. van Koningsveld, Moslims in Nederland: Minderbeden en Religie in een Multiculturele Samenleving, Houten: Bohn Stafleu Van Loghum, 1997, p. 44.

${ }^{19}$ Laugu, Mosque, p. 249. 
Muslims, as a minority group in the country, try to keep their own Islamic identity through the efforts of making their mosque as a centre for religious and non-religious activities, such as the celebration of the Islamic holidays like the anniversary of the prophet Muhammad and other social activities, including regular meetings between the members of the different Islamic groups, let's say Indonesian, Pakistan, and other Muslim groups. Almost all Islamic social activities were conducted in the mosques. Therefore, the members of the groups feel that it is important to provide different collections in the mosques, which are then said to have mosque libraries, in order to support the independent learning and information searching among Muslim communities in their own mosques. As a result, it will be easier for them to get information regarding both religious and social matters. ${ }^{20}$

\section{a. Social Role}

Amid the Muslim society in general, mosques are considered favourable places by Muslim people to perform a ceremony or a celebration of certain events, both religious and social. It is historically accounted that the prophet had permitted the people of Sudan and Abyssinia to conduct festivals in the mosques. There are two great festivals which are still performed in the mosques: the first festival is Idul Kurban or Idul Adha happening in the Pilgrimage season. The second one is Idul Fitri indicating the end of Islamic Fasting Month. In addition to that, there are still many occasions which are celebrated in the mosques, such as Muslim New Year and Ashura Day, a special event for the followers of the Syi'ah Sect. ${ }^{21}$

As a centre for social activity, mosques were usually visited by both kings and ordinary people. Mu'awiyah, the first caliph of Umayyad, usually sat and talked with his physics expert, Ibn Uthal, in the Damascus mosque. In most groups of Muslims, the transactions of marriage and divorce have been commonly performed in mosques.

\footnotetext{
${ }^{20}$ For further information about mosque libraries in the Netherlands, see in detail my article published in Mukaddimah (No. 19 TH. XI/2005), page 245-270 entitled Mosque Libraries in the Netherlands: an Explorative Study.

${ }^{21}$ Such events have been done by Muslims all over the world, including the Assura Day, which the followers of the Shi'ah Sect celebrate each year.
} 
Talented speakers, known as story teller (Qussas), Wuaz, Muthakirun, or Speaker (Mutakallimun), attended the mosques in which they were telling popular stories or other discourses for the entertainment and education of the audience. ${ }^{22}$

Besides, medical services have also been provided in the mosques for all members. Abd al-Wahhab narrates that when the mosque Sultan Hasan in Cairo was opened in $757 / 1356$, the donator of the mosque, Sultan Hasan, announced that there would be a team, consisting of open practitioners, optometrists, and surgeons, as a public administration of the mosque. Each three days, doctors would come to the mosque to give medical services for students and others. According to al-Maqrizi, Ibn Tulun mosque in Cairo had a special room for medical supplies. Every Friday, a doctor came and served people of the mosque who needed medical help. In his book concerning mosques and Islamic propagation, Husain reveals that beside a place of worship, the mosque also functions as an office of courts, educational institutions, polyclinics, and pharmacies. ${ }^{23}$

The position of mosque libraries in the context of social roles is designed as an information provider in order to support the social activities among the Muslim communities, such as the activity of oration. Therefore, the mosque libraries sought to collect information or collections regarding the topics orated. Thus, the orators were expected to be able to find their topics in the mosque libraries. Besides, the medicine information should also be provided in the mosque libraries so that the pharmacists could find or even borrow collections from the libraries. ${ }^{24}$

\section{b. Political Role}

Besides being a centre for social activity among Muslims, mosques also function as centres for political activities. Most Muslims

${ }^{22}$ Sibai, Mosque, p. 17.

${ }^{23}$ Ibid., p. 19 and See "masdjid" in the Encyclopaedia of Islam (WebCD Edition by Brill Academic Publishers, 2003). For further information, Mehdi Nakosteen in History of Islamic Origins of Western Education A.D. 800-1350: with an Introduction to Medieval Muslim Education, Colorado: University of Colorado Press, 1964, p. 72.

${ }^{24}$ Ibid., p. 20. 
believe that such a development is unavoidable. This supports the claim that anything done by the prophet is connected with the mosques. In line with this issue, mosques have become centres for political and religious matters among the Muslim society. The mosques are places for the faithful to gather and pray around the prophet. In a similar environment, he encountered his audience for several reasons: reminding his followers to stay obedience to God and following the Islamic rules concerning the social life of society, and relying on the issue that he, the prophet, guided his followers or friends, both in religious and non-religious matters such as politics and economy.

The relationship between mosques and politics, then, is something interesting. After each conquest done by Muslims in the beginnings of Islamic society, they always sought to build mosques and placed them in the centre of the city where the rulers lived, called the Dar al-Imarah..$^{25}$ In several communities, the mosques were built next to the Dar al-Imarah showing that the two structures of both buildings are side by side. This side by side picture illustrates a public consensus that the rulers were the holders of the highest political and religious authority among the Islamic society. Some people argue, by relying on this issue, that Islam and politics are two things which cannot be separated. In early Islamic civilization, the highest leader (holder of power) of these two is the person called the caliph. The caliph was the leader responsible for both religious and political activities. Both matters were administrated in the mosque, which, at that time, was indeed known as a centre of gravitation for religion and politics.

An indication showing the close relation between the rulers and the mosques was the tradition to provide special rooms for the caliph in the mosques, for himself and for his successors. All kinds of activities performed in the mosques were funded by the caliphs themselves. As a consequence, in all places where Islam had been accepted, the name of the caliph was always mentioned in every event in the mosques

${ }^{25}$ Referring to the meaning provided in the Encyclopaedia of Islam (WebCD Edition by Brill Academic Publishers, 2003) and the Elias' Modern Dictionary (ArabicEnglish) by Elias A. Elias and Ed. E. Elias, the word "Dar" can be synonymised as Door or Gate and House while the "Imarah" means as a principality or princedom which refers to places where the rulers live to lead their people. 
where the Muslims come together to perform their praying, particularly on the Friday praying. ${ }^{26}$ This illustrates that Muslims living in different regions or districts proved their loyalties to the caliphs. ${ }^{27}$

The mosque libraries in this context also played a significant role of supporting the continuity of Muslims knowledge concerning political affairs, on which they obtained collections. Therefore, it is not surprising if mosque libraries would have collected books on various different subjects, not only religious, particularly ritual, topics, but also general subjects covering political and social issues. As mentioned above, the mosque libraries are designed to provide information relating to all activities of communities, especially in relation with Islam. As a result, most mosque libraries serve collections on politics, medicine, economy, and so on. ${ }^{28}$

\section{c. Educational Role}

Since the beginnings of Islamic society, the process of learning and teaching has been extensively associated with the mosques. Up to now, these learnings and teachings, that take place in the mosques, give Muslims an opportunity to master Islamic values and to implement them in their daily lives as a fundamental way to encounter the living world. ${ }^{29}$ Learning to memorize and understand the Qur'an is the starting process of education and teaching conducted in the mosques. The further step is to learn the sayings of the prophet Muhammad concerning the conceptual explanation, to comprehend the right concept of Islamic belief illustrated by the Qur'an. The prophet Muhammad had based his teaching in the mosque on both religious and non-religious matters. According to some writers, by doing so, mosques and learning activities grew to become two inseparable factors. ${ }^{30}$ Focusing on the basic Islamic doctrines, it is reasonable to argue that mosques have been intensively

${ }^{26}$ See "Masdjid" in the Encyclopaedia of Islam (WebCD Edition by Brill Academic Publishers, 2003).

${ }^{27}$ Sibai, Mosque, p. 22.

${ }^{28}$ Ibid., p. 23-24.

${ }^{29}$ Ibid., p. 25.

${ }^{30}$ Tritton, Arthur S., Materials on Muslim Education in the Middle Ages, London: Lusac, 1957, p. 185. 
used as centres for teaching activities among Islamic communities in the first several decades of Islamic propagation.

To prevent the mentioned views concerning the Islamic education from being regarded as a little bit simplistic, I hold it important to highlight that the transformation of mosques into the first schools of Islam is not a coincidental phenomenon. There is much evidence that the prophet was heavily expecting the mosques to become crucial locations within the educational process of the Islamic society. It is accounted that the prophet often tried to teach his followers in Mecca in the Holy Haram, before his move to Madinah, however he failed; this indicates that the mosque is a significant place for learning activities. In these conditions, the opponents of the prophet never allowed him to do so. Their behaviour was not only opposing, but he and his followers were even humiliated and tortured. Therefore, the prophet tried to meet and teach his followers secretly, occasionally in his house or in the house of Ibn al-Arqam, a close follower of the prophet. ${ }^{31}$

Up until now, the mosques have been famously known as important centres for education as well as worship. Both roles have been continuously performed in Islamic history, including the eras of Umayyad, Abbasid, and so on. When Islam was firstly propagated, the mosques were built in order to support the instructional activities, both religious and non-religious, which then became widely available in the early Muslim societies. During the initial formation of Islamic communities, the basic levels of learning among the communities were given by teachers instructing in the mosques. Several mosques had been transformed into important and distinguishing schools which attracted some famous scholars, such as al-Ghazali. ${ }^{32}$

In such circumstances, the mosque libraries became very important and were necessary to support the process of learning and teaching. It is generally believed that learning based only on teachers will be extremely limited due to the lack of time available, so that mosque libraries were strongly expected to provide different collections to support instructional activities in the mosques. Throughout Islamic

${ }^{31}$ Al-Ibrasyi, Muhammad Atiyah, Al-Tarbiyah al-Islamiyah wa-Falasifatuha, Cairo: Isa al-Babi, 1969, 72.

${ }^{32}$ Nakosteen, History, p. 48-49. 
history, a lot of examples prove such contribution of mosque libraries; some mosques with large libraries developed into centres for higher education, such as the mosque of al-Azhar in Cairo. ${ }^{33}$

\section{Mosque Libraries in the Islamic History of Middle East and its Surroundings}

In writing her background of history of Islamic libraries, Ruth Stellhorn Mackensen reveals that a lot of books were served and were indeed endowed by many bibliophiles and scientists in the beginnings of Islamic history. By doing so, they supported library collections of mosques spread over many Muslim regions. Such endowment was commonly practiced because it was believed, by the owners of the books, to be a good way to preserve their private collection as well as to open public access for the society as a whole. It is, therefore, important to be noted that not all mosques have their own collections; they were usually given responsibility as a mediator between the owners of the collections and its users. ${ }^{34}$ These kinds of collections were typically located in the mosques Jami', Masjid Jami'; and it is therefore not difficult encounter collections of books in the Masjid Jami ${ }^{35}$

Regardless of the location and the size, most mosque libraries were etymologically called as Maktabah, Khazain al-Maktabah, and Qur'anic Libraries, which became famously known due to the fact that the mosques or mosque libraries were obliged to provide a Qur'an collection. Such phenomena are typical in Islamic societies, where the Qur'an became the main object of collection. In line with the issue referring to Abu Bakar al-Maliki, Shabuh states that the old library of Qairawan Mosque in Tunisia had developed from the endowment of voluminous books, including the holy Qur'an. The other books were bequeathed by local scholars and famous families. ${ }^{36}$

Before discussing the services and the collections of books provided in the mosque libraries, the writer would first of all like to

${ }^{33}$ Sibai, Mosque, p. 27-28.

${ }^{34}$ Eche, Les Bibliothàques, p. 271-272.

${ }^{35}$ Sibai, Mosque, p. 50.

${ }^{36}$ Al-Nadim, Muhammad Ibn Ishaq, Kitab Fibrist, ed. Gustav Flugel, Leipzig: Verlag Von F.G.W. Vogel, 1872, p. 8, 29. 
highlight the development of some mosque libraries in a glance of historical views. It is important to note here that the views will be focused only on the libraries which are regarded to have contributed to the development of Islamic society and to have represented the Islamic libraries a long the history of Islam. It is emphasized that it would be impossible to explore all kinds of mosque libraries in this study; therefore, those libraries will be classified into two groups based on the geographical location.

\section{Muslim of Spain and North Africa}

The first group of mosque libraries to be elicited here is located in Spain and North Africa, which were firstly expanded by the Muslim power in the year 93/711. It is accounted that most of the Iberian Peninsula, which, in Arab history, was called Andalusia, was successfully defended by Muslims until the year 898/1492 when the Alliance troops of King Ferdinand V and the Queen Isabella of Castile successfully defeated the Kingdom of Granada, the last stronghold of Muslims in the Peninsula. During the rule of the Muslims in Spain, they had established a lot of mosques, most of which had been equipped with good collections used by the people who did not have private libraries. One of the famous mosque libraries was attached in the great mosque of Cordova. ${ }^{37}$

In North Africa, we will focus on one of the greatest, oldest, and most famous mosques, built in the year 245/859, funded by a rich woman named Fatima al-Fihri. This mosque, Masjid Qarawiyyin, is located in Fez and used to have three separated libraries; the first one is the Library of Abu Inan which was the most prestigious and was also known as a scientific library. ${ }^{38}$ The second one is the library of Abu Yusuf, which name was taken from Abu Yusuf Ya'qub, a king who lived before the time of the mosque. The third library, Mansuriyah, was built by a king who was also a scholar named Ahmad al-Mansur

\footnotetext{
${ }^{37}$ Sibai, Mosque, p. 54-55.

${ }^{38}$ Al-Jarari, Abd Allah Ibn al-Abbas, Taqadum al-Arab fi al-Ulum wa-Alsinnah waUstariyatabum li-Awruba, Cairo: Dar al-Fikr al-Arabi, 1961, p. 228.
} 
al-Dhahabi, around the year 996/1587.39

Tunisia is a country with a good history of mosque libraries dating from the initial formation of Islamic communities. There were two important mosque libraries belonging to the Qayrawan and Zaytuna mosques. The former is also known as Masjid Jami' Uqba, which according to history was constructed by an army leader around 50/ 670 or 60/680. Being built far before al-Azhar, the Qayrawan mosque was the main centre of culture and education in entire North Africa. Public education and Qayrawan are the two inseparable things. Therefore, the mosque provided open opportunities to all potential participants, particularly women, so that they could contribute actively in the development of education and knowledge in the mosque libraries. ${ }^{40}$

Beside Morocco and Tunisia, Egypt ${ }^{41}$ was the third North African country where the mosque libraries had well developed. For example, the costal area of the ancient city of Alexandria had at least two mosque libraries. The oldest library of the city was attached to the mosque Jami' Syaikh Ibrabim Pasya, and is also known as the mosque Syaikh. The mosque was established by Syaikh Ibrahim, a scholar as well as donator originally from Morocco. Beside the above name, the mosque is also popularly known as a mosque al-Anwar, 'the shines'. It is accounted that the mosque was designed as an institutional location, offering room for six hundred students. Several years later, the mosque was known as al-Azhar Alexandria. The mosque has tremendous amounts of publicated books and manuscripts in different subjects. The other library belonging to Alexandria was placed in the mosque of Abi al-Abbas al-Mursi, established by Abd al-Fattah al-Banna, a scholar of Alexandrian origin, in the transitional century. ${ }^{42}$

${ }^{39}$ Al-Fasi, al-Abid, "Khizanah al-Qarawiyyin wa-Nawadiruha" in Majallab Mahad al-Makhtutat al-Arabiyyah 5 (May 1959: 4).

${ }^{40}$ Sibai, Mosque, p. 58.

${ }^{41}$ The writer decided to include Egypt as one of the North African countries following the opinion of Sibai in Mosque Libraries: An Historical Approach (1987: 63).

${ }^{42}$ Khairi, Ahmad, "Bad al-Maktabah al-Qayyimah al-Khassa al-Lati Kanat biMisr fi-Hadha al-Asr wa-Indatharah" in Majallah Mahad al-Makbtutat al-Arabiyyah 10 (May 1964: 188-9). It is noted that some books did escape the bombing. However, as Khairi observed: "What escaped destruction did not escape the hands of those who had no moral scruples" see also Sibai, Mosque, p. 61. 
Not only Egypt, Tunisia, and Morocco could feel proud by having great and excellent mosque libraries. The other North African countries also had great and amazing mosque libraries, like those from Algeria and Libya mentioned by Ahmad. In Algeria, the libraries, which were attached to Jadid-mosques located in the cities, were discovered to possess one hundred rare manuscripts. In Libya, Kaak reveals that its library was placed in the mosque Aazzam in the costal city of Tripoli, and that its collection was recorded to be great and amazing. ${ }^{43}$

\section{Arab Near East}

The second group of mosque libraries to be discussed is situated in the Arab countries at the Near East. It is significant to be emphasized here that this section of the investigation of the important examples of libraries is to be explored further, particularly the libraries that are well accounted in the historical records.

Al-Sham is a stony and rocklike area in the eastern Islamic kingdom. A classification of the Muslim-Arab for the regions covering Syria, Lebanon, Palestine, and Jordan, al-Sham was the first protectorate area of the ancient Greek-Roman Alliance to be defeated by a Muslim power. Within the process of religious conversion to Islam, the regions of al-Sham were quickly defeated. One of the fundamental causes is the propagation of Muhammad's messages. The mosques, which had been developed by the study-circles, were built everywhere, and afterwards collections were emerged for the people in pursuit of all kinds of information. ${ }^{44}$

Although Al-Sham was the heart of the Muslim Arabic Near East, the Arabian Peninsula was the first region attracted by Islam. The central target of the messages of the prophet Muhammad was the city of Mecca and the mosque of Haram, the holy mosque. At the early days of Islam, the Haram mosque had become an excellent place for students and their teachers. It is accounted that the prophet came back to Mecca in the year 8/629, after living for eight years in Medina; he left his trusty follower, Muaz, to teach the basic concepts of Islam to those interested to learn them. It was also reported that the other

\footnotetext{
${ }^{43}$ Sibai, Mosque, p. 68.

${ }^{44}$ Ibid., p. 69.
} 
followers such as Abdullah Ibn Abbas usually sat in the mosque of Haram where he taught the exegesis of the Qur'an, the sayings of the prophet, law, and literature. ${ }^{45}$

The Arabian Peninsula is the place where Islam came from, but Iraq was the place usually aimed at to get power for political movements. It is recorded that no Muslim dynasty ruled longer or was more famous than the Abbasid caliphate, from 133/750 to 656/1258. The caliphate started its power from Baghdad to other different places; during its rule, the Abbasid Caliphate had become a patron of knowledge which made it more tolerant in terms of practicing religion. The caliphate had led the development of Islamic civilization through moderate ways, which did not compel its values to non-Muslims, so that the individual rights of each member of society became a source of inspiration to the living world. All people possessed their own right to express whatever they regarded a true way for their lives. ${ }^{46}$

\section{The Important Management Role in Running Mosque Libraries}

Borrowing books is not the only variable indicating whether or not a person is educated. It is just one of the measurements which can be used to assess the qualification of a person. The mosque libraries have been designed to provide opportunities for all people of the mosques to get access to information. Most of mosque libraries were placed in a room separated from prayer room, with exception of the very small and simple mosque libraries. Some of them have been designed in a certain building which is usually next to the mosque building. These libraries are expected to be able to fulfil all needs of different users. In proportion to the usage of the mosque libraries, which historically dated from the initial emergence of the mosque libraries until the period of their brilliant development, they had played the roles of public libraries. These roles can be seen from two perspectives; their collections were not limited to a certain subject,

${ }^{45}$ Al-Khuli, Ali Muhammad al-Shadili, Dawr al-Masajid al-Tarikhi fi al-Tahqif alIlmi (Cairo: Wazarat al-Awqaf, 1961), p. 15.

${ }^{46}$ Sibai, Mosque, p. 78 and see also Kurkis Awwad. "Tatawur Fahrasah alMakhtutah fi-al-Iraq” in Majallah al-Majma’ al-Ilmi al-Iraqi 23 (1973: 143-7). 
and they were designed for all kinds of users regardless of social status, ethnicity, race, religion, and so on. ${ }^{47}$

Regarding the name giving on the mosque libraries, it is important to explain here that the names of the mosque libraries are mostly taken from the names of mosques where the libraries are attached to. For example, the mosque library of al-Azhar is belonging to the mosque al-Azhar in Cairo; just like the mosque library of Cordova belongs to the mosque of Cordova, etc. In such circumstances, during the early history of Islam, covering an area from the Atlantic Ocean to the Persian Gulf, Muslims have regarded their places of worship as paradises for keeping their own valuable collections. It is accounted that the collections placed in the mosques had attracted many people's attention to be involved in supporting the continuity of these libraries. Many examples prove such continuation, as can be seen from the mosque libraries of Andalusia which were attached to the Jami' mosques of Cordova, Malaga, and Seville, as well as the Byazin mosque in Valencia. ${ }^{48}$

Building libraries in the mosques is generally done at the time the intended mosques are well established. In certain communities, however, the mosques are sometimes built together with the libraries in a design in which the two can be equipped simultaneously. In line with the issue, mosques are built by many different people from various interests and backgrounds such as ethnicity and social status. It is also interesting to notice that many rulers were involved in promoting the importance of having collections of books, particularly those belonging to the mosques and mosque Jami'. As a consequence, due to the close relations between Islam and the development of knowledge during the Muslim dynasties, especially in its initial eras, Islamic rulers became donators and promoters for the development of libraries, among which mosque libraries. It is accounted that due to the availability of good libraries, many people are known to have obtained great attention to

${ }^{47}$ Such circumstances can be read about in many different Islamic books concerning the libraries and the development of knowledge in Islamic society, particularly in the time of al-Makmun, the Abbasid caliph who was one of the biggest admirers of scientific movements a long the history of Islam.

${ }^{48}$ Sibai, Mosque, p. 88. 
knowledge and some rulers are recorded to have propagated religious and political ideologies consisting of material from the mosque libraries.

In such circumstances, collection development has become fundamental to introduce certain ideas, particularly those belonging to the incumbent rulers. It is accounted that the development of library collections was achieved in several ways, such as multiplication (rewriting documents), purchase, and donation. All kinds of acquisitions were written on the list in order to provide transparent management for the libraries, which were then expected to become a basis for further acquisition. Transactions determining whether certain pieces of those collections were donations or purchases were clearly recorded. It is noted that in the mosque libraries, the donation system has been much promoted and developed in order to develop the libraries. Therefore, it is clear that donation in the mosque libraries was fundamental to build up a good collection. ${ }^{49}$

In either case, there were in early days of Islamic history various mosque libraries with a big collection. It is related that the library of Haydariyah Jami’ Mosque, Najaf Iraq, had a large collection numbering between forty thousand and four hundred thousand volumes, and that the Zaytuna mosque in Tunisia possessed more than one hundred thousand volumes. The other famous library belonged to Mosque Ahmadiyah. It had a collection totalling at least thirty six thousand volumes in its shelf. ${ }^{50}$

Besides, it is also important to investigate the historical relationship between mosque education and mosque libraries concerning Islamic education. This is specifically important because the collections provided in the libraries were coloured by mosque education, in the sense that the subjects and even ideological perspectives of education have largely affected the subjects and contents of the collection. Mosque libraries from now onwards have provided a variety of collections consisting of different perspectives towards religious and social movements such as Syi'ah and Sunni. Such perspectives can be seen in many different subjects, e.g., in the exegesis of the Qur'an, the sayings of the prophet and other related subjects

\footnotetext{
${ }^{49}$ Ibid., p. 92-93.

${ }^{50}$ Ibid., p. 96.
} 
such as Islamic theology and legislation. In relation to the issue, the mosque libraries have collected subjects as literature, sociology, and other scientific matters including medicine, mathematics, etc. For example, the Moroccan government in the year 1380/1960 published a list consisting of 250 manuscripts found in the collection of the Qarawiyyin mosque in Fez. ${ }^{51}$

Collection development is the starting point for libraries, particularly the mosque libraries, to provide good services to the users. Therefore, librarians are expected to be really industrious in obtaining a good collection, which then would result into good services fitting the demands of the users. The next step is to process the collections enabling users to retrieve their needs of information effectively and efficiently. Thus the mosque libraries should obtain different tools which can help them to locate everything they need. The libraries usually obtain pathfinders, lists of titles, catalogues, etc. which have the function to guide the users without the guidance of the librarians. Therefore, the roles of the librarians are not only to give direct help to the users, but also to create a variety of tools functioning as mediators between users and collections. For example, al-Fasi wrote that when the mosque library of Abu Inan was established in the year 750/1349 in mosque Qarawiyyin in Fez, the founder, Sultan al-Mutawakkil Abu Inan, appointed a librarian whose main work was to list all collections presented in the mosque library. ${ }^{52}$

In the contexts of mosque libraries, the availability of collections is sometimes associated with active librarians and their staff, who mostly do not have a regular budget to run their all activities, particularly the acquisition of a collection. Therefore, if the librarians are not professional in looking for good collection, libraries will face big problems with their collections. Generally, mosque libraries in Islamic history have only relied on the donation of people, who had affinity towards the libraries, including the caliphs. Besides increasing the collection, librarians are also expected to be professional in cataloguing it, so that the users can retrieve information easily. Therefore, it is

${ }^{51}$ Ahmad, Muhammad Abd al-Qadir, Dirasah fi-al-Turath al-Arabi, Cairo: Maktabah al-Anglo, 1979, p. 239.

${ }^{52}$ Sibai, Mosque, 1987: 100. 
vital that big mosque libraries should single out a proper classification which can help their users effectively to locate their desired pieces from the collection. ${ }^{53}$

Beside cataloguing and classification, mosque libraries also have to facilitate reading rooms, which may also be used for writing assignments of the students. There are several libraries of mosques that have provided such facilities, particularly the ones belonging to bigger mosques. Even though there is no evidence in terms of chairs and tables being used, it is accounted that there were sorts of carpets, mattresses, and other facilities supporting the activities of learning in the mosque libraries. An example proving such conditions is the mosque library of Qarawiyyin, where Sultan al-Mutawakkil Abu Inan instructed to design a certain room for reading which is famously known as a reading room. ${ }^{54}$

Regardless of being focused on collections or on facilities, the main power of the mosque libraries is the capability of accommodating and fulfilling the needs of the users. By writing an article concerning the influences of libraries in the promotion of Islamic education, Shafi revealed that the freedom of getting access to books for all people is a sine qua non of public libraries of Arab, where all facilities were provided, and which could thus be regarded as better than modern libraries. ${ }^{55}$ Beside the free access and the circulation of their collections, mosque libraries also provided several other services like copying books in the libraries. It is important to be mentioned here that lending books to others is one of the Muslim traditions in Islamic history. It is accounted that the prophet Muhammad said that the first blessing to people is the activity of transmitting Islamic tradition to others or to the following generations, or, in other words, the right to lend each other's books. ${ }^{56}$

Therefore, mosque libraries are similar to other Islamic libraries to the extent that their librarians are heavily expected to be able to

\footnotetext{
${ }^{53}$ Ibid., p. 102.

${ }^{54}$ Levi-Provençal, Evariste, Nukhab Tarikhiyyah Jamiah li-Akhbar al-Maghrib alAqsa, Paris: La Rose, 1948, p. 68-9.

${ }^{55}$ Shafi, Muhammad, "Libraries and Learning in the Muslim World" in Pakistan Library Review 3 (March 1961: 35).

${ }^{56}$ Sibai, Mosque, p. 105.
} 
fulfil all its users' needs. In order to achieve this goal, the librarians had to be professional and preferably from an educational background. In Islamic terms, the librarians are known by several names, namely: Nathir, Sabib, Qayyin, Muhafir, Khazin, or Amin, whose jobs consisted of working for mosque libraries. Al-Fasi related that during the establishment of the library in the Qarawiyyin mosque in the year 750/ 1349, the Sultan of Fez, al-Mutawakkil Abu Inan, appointed a librarian to be responsible for the mosque's collection. ${ }^{57}$

Besides, the appointment of librarians became in many cases the monopoly of the founders of the libraries or their successors and descendents. There is evidence that the librarians were assigned in this way by the rulers or their representatives, including the heads of the mosques. It is recorded that such staffing can result into fragile situations, because it sometimes leads to problems of collusion. Therefore, it is of importance to use professional approaches and avoid conspiracy in terms of recruiting new library staff. The importance of the epithet "professional" in relation to library staff, it seems, has unfortunately not always been sufficiently remembered, though not many would disagree that hiring qualified librarians will provide good opportunities to the development of mosque libraries. The library of the Abyad mosque, established in 812/1409, clearly states that librarians should be qualified in knowledge, polite, honest, pro-active, sincere, greedy, etc. ${ }^{58}$

\section{E. Stagnation Era of Mosque Libraries}

Sporadic actions of un-professionalism done by corrupt and unhonest librarians are proven to be fatal for the mosque libraries along the history of librarianship in Muslim communities. Therefore, there should be awareness among those responsible for the continuity of the development of libraries in the future. We must realize, however, that such phenomena are no single entity; we should acknowledge that each entity stands in connection with the others. Good libraries will lead to good education and vice-versa. This experience should become a guide for those who still support the thought that education needs

\footnotetext{
${ }^{57}$ Ibid., p. 109.

${ }^{58}$ Ibid., p. 109-115.
} 
good libraries, so that the users are able to improve their education independently. ${ }^{59}$ Unfortunately, such awareness had become a thing smaller than it is expected to those who were responsible for the mosque libraries. Besides, there were also different attacks, such as firing libraries and taking away their collections, done by non-Muslim that were called as an external factor. In such circumstances, the mosque libraries had not been able to play significant roles in terms of religious, social, political, and educational affairs. The following are several factors contributing to the decline of the mosque libraries' contribution towards Muslim society along the Islamic history.

\section{Internal Factors}

One of the internal factors that brought about the stagnation of mosque libraries is the attitude of Muslims themselves. They were careless in maintaining the collections of the mosques, so that many good collections, among which rare books and manuscripts, were stolen or damaged due to their own lack of attention. It was even more aggravating that some collections had been stolen by librarians themselves. In addition to that, many mosque libraries were damaged by internal conflicts, both public and ideological, which on their turn provided room for the establishment of heterodox sectarian movements, resulting eventually into the burning of many books considered to be against the teachings and ideologies of certain groups or societies. ${ }^{60}$

\section{External Factors}

Intimidating and harmful actions by non-Muslims, regarded as outsiders, are the first recorded external factors that attributed to the stagnation of mosque libraries. Ahmad relates that many mosque libraries had been robbed and damaged by Italian and French troops. ${ }^{61}$ Referring to historical sources, Ibn Abi Dinar al-Manuni wrote that during the Spanish's conquest in Tunisia in the year 980/1572, many collections of the Zaytuna mosque were damaged and stolen by the attackers. Ibn Abi Dinar furthered his account that the streets around

${ }^{59}$ Ibid., p. 116.

${ }^{60}$ Ibid., p. 119-120.

${ }^{61}$ Ahmad, Dirasah, p. 157. 
the mosque were full of dirty books from the library of the Zaytuna mosque. $^{62}$

\section{Other Disasters}

Beside the above-mentioned external and internal factors, such as conflicts concerning interests and ideology, natural disasters like earthquakes, floods, and other catastrophes have also afflicted collections of mosque libraries. It is, however, difficult for us to determine when to blame nature and when to blame mankind, because, to make it even more complicated, it is also possible that a natural calamity happens due to human carelessness. In any case, it is also important to emphasize that natural disasters, whether or not triggered by human actions, are often beyond human expectations. Regarding the history of mosque libraries, many mosque libraries have encountered such environmental disasters. It is evident that many earthquakes have affected mosques in Islamic regions, for example in Damascus in the year 131/748. ${ }^{63}$ Not only the collections, but even the people were victimized during that natural catastrophe. ${ }^{64}$

\section{F. Conclusion}

Mosque libraries have developed into big assets within Muslim communities along the history of Islamic civilization. It is clearly accounted that the role of mosque libraries in these contexts is very obvious and emphatical during the Islamic formation. The mosque libraries were extremely developed in order to be able to support all their activities programmed by their main institutions, the mosques. They were proven to play not only religious, but also of non-religious -such as social, political, and educational- roles. Each of these functions was recognized publicly, and mosque libraries even became the central domain for Islamic institution in the long history of Islamic development and religiosity all over the world. This situation becomes clearly visible

${ }^{62}$ Sibai, Mosque, p. 117-118.

${ }^{63}$ Al-Munajjid, Salah al-Din (ed.), Masjid Dimashq, Damascus: al-Maktabah alHashimiyyah, 1948, p. 11-19.

${ }^{64}$ Sibai, Mosque, p. 123-124. 
if we focus on the historical context of the mosque libraries emerging in the Middle East and in surrounding regions.

Next to that, mosque libraries possessed very specific and developed operational systems, as well as standardized operational procedures able to conform their services to the needs of the users. These highly developed operational methods -such as regulations concerning the appropriate size of rooms in relation to the amount of books, and accurate measurement of the increase of the collectionswere designed in order to fulfil one of the main functions of the libraries; achieving the vision and goals of the mosque in an optimal way.

Finally, the situation of stagnation and the era of decline of the mosque libraries are treated. There are several factors contributing to this gloomy era. For example, external factors like intimidating actions and damaging activities which were carried out by foreign powers to the Muslim world. But internal factors, on the other hand, were also very influential to the decline of mosque libraries. In this light we should regard carelessness of the librarians and other staff working in the mosque libraries, behaviour that has resulted into mismanagement of the libraries and even into theft from the rare and valuable collections. The last group of factors are natural disasters such as earthquakes and floods, which can of course tremendously influence the continuity of the mosque library collections. 


\section{BIBLIOGRAPHY}

Ahmad, Mirza Tahir, Revelation, Rationality, Knowledge, and Truth, United Kingdom: Islam International Publications Limited, 1998.

Ahmad, Muhammad Abd al-Qadir, Dirasah fi-al-Turath al-Arabi, Cairo: Maktabah al-Anglo, 1979.

Ali, Abdullah Yusuf, The Holy Qur'an: Text and Translation, Kuala Lumpur: Islamic Book Trust, 1994.

Awad, Gurgis, Khizanah al-Kutub al-Qadimah fil-Iraq, which is a translation from the title Ancient Libraries of Iraq: From the Earliest Times to the Year 1000 A.H. (1591 A.D.) published by al-Maarif Printing Press of Baghdad in 1948.

Bashiruddin, S., "The Fate of Sectarian Libraries in Medieval Islam" in Libri: International Library Review, Vol. 17 (1967: 149-162).

Ben-Aicha, Hedi, "Mosques as Libraries in Islamic Civilization, 7001400 A.D." in The Journal of Library History, Vol. 21, No. 2 (Spring 1986: 253-260).

Bukhsh, Khuda, "The Islamic Libraries" in The Nineteenth Century and After, Vol. 52 (July-December 1902: 125-139).

Eche, Youssef, Les Bibliothèques Arabes: Publiques et Semi-Publiques en Mèsopotamie, en Syrie et Égypte au Moyen Age, Damas, 1967.

Al-Fasi, al-Abid, "Khizanah al-Qarawiyyin wa-Nawadiruha" in Majallah Mahad al-Makhtutat al-Arabiyyah 5 (May 1959: 4).

Al-Ibrashi, Muhammad Atiyah, Al-Tarbiyah al-Islamiyah wa-Falasifatuba, Cairo: Isa al-Babi, 1969.

Imamuddin, S.M., "Hispano-Arab Libraries, Books and Manuscripts: Muslim Libraries and Bookmen in Spain" in Journal of the Pakistan Historical Society, Vol. 52, Part 1 (January 1959: 101-119).

-, Some Leading Libraries of the World. Dhaka: Islamic Foundation, 1983.

Jarari, Abd Allah Ibn al-Abbas al-. Taqadum al-Arab fi al-Ulum waAlsinnah wa-Ustaziyatahum li-Awruba, Cairo: Dar al-Fikr al-Arabi, 1961. 
Khairi, Ahmad, "Bad al-Maktabah al-Qayyimah al-Khassa al-Lati Kanat bi-Misr fi-Hadha al-Asr wa-Indatharah" in Majallah Mahad alMakbtutat al-Arabiyyah 10 (May 1964: 188-9).

Al-Khuli, Ali Muhammad al-Shadili, Dawr al-Masajid al-Tarikbi fi alTahqif al-Ilmi, Cairo: Wazarat al-Awqaf, 1961.

Kurkis Awwad, "Tatawur Fahrasah al-Makhtutah fi-al-Iraq" in Majallab al-Majma' al-Imi al-Iraqi 23 (1973: 143-7).

Laugu, Nurdin, "Mosque Libraries in the Netherlands: an Explorative Study" di Mukaddimah: Jurnal Studi Islam, No. 19 TH. XI/2005 (hlm. 245-270).

Levi-Provençal, Evariste, Nukhab Tarikhiyyah Jamiah li-Akbbar alMaghrib al-Aqsa, Paris: La Rose, 1948.

Mackensen, Ruth Sellhorn, "Background of the History of Muslim Libraries" in The American Journal of Semitic Languages and Literatures, Vol. 51 (October 1934-July 1935: 114-125), Vol. 52 (October 1935-July 1936: 22-33, 104-110).

Mackensen, Ruth Stellhorn, "Arabic Books and Libraries in the Umaiyad Period" in The American Journal of Semitic Languages and Literatures, Vol. 52 (October 1935-July 1936: 245-253), Vol. 53 (October 1936-July 1937: 239-250), Vol. 54 (October 1937: 41-61), Vol. 56 (January-October 1939: 149-157).

Mackensen, Ruth Stellhorn, "Four Great Libraries of Medieval Baghdad" in The Library Quarterly, Vol. 2, No. 3 (July 1932: 279299).

Mackensen, Ruth Stellhorn, "Moslem Libraries and Sectarian Propaganda" in The American Journal of Semitic Languages and Literatures, Vol. 51 (October 1934-July 1935: 83-113).

Makdisi, George, The Rise of Colleges: Institutions of Learning in Islam and the West, Edinburgh: Edinburgh University Press, 1981.

Al-Munajjid, Salah al-Din, (ed.). Masjid Dimashq, Damascus: alMaktabah al-Hashimiyyah, 1948.

Al-Nadim, Muhammad Ibn Ishaq, Kitab Fibrist, ed. Gustav Flugel, Leipzig: Verlag Von F.G.W. Vogel, 1872. 
Nakosteen, Mehdi, History of Islamic Origins of Western Education A.D. 800-1350: with an Introduction to Medieval Muslim Education, Colorado: University of Colorado Press, 1964.

Pedersen, Johs, "Some Aspects of the History of the Madrasa" in Islamic Culture, Vol. 3 (1929: 525-537).

Pinto, Olga, "The Libraries of the Arabs During the Time of the Abbasides" in Islamic Culture, Vol. 3 (1929: 210-243).

Prince, Chris, "The Historical Context of Arabic Translation, Learning, and the Libraries of Medieval Andalusia" in Library History, Vol. 18 (July 2002: 73-87).

Shadiq, W.A.R. and P.S. van Koningsveld, Moslims in Nederland: Minderheden en Religie in een Multiculturele Samenleving, Houten: Bohn Stafleu Van Loghum, 1997.

Shafi, Muhammad, "Libraries and Learning in the Muslim World" in Pakistan Library Review 3 (March 1961: 35).

Sibai, Mohamed Makki, 'Mosque Libraries' (Book Review) in the Journal of Library History. Vol. 8 (1988).

Sibai, Mohamed Makki, Mosque Libraries: An Historical Study, London: Mansell Publishing Limited, 1987.

Spies-Aligarh, Von Otto, "Die Bibliotheken des Hidschas" in Zeitschrift der Deutschen Morgenländischen Gesellschaft, Band 90 (Neue Folge Band 15), Leipzig (1936).

Tritton, Arthur S., Materials on Muslim Education in the Middle Ages, London: Lusac, 1957. 